IIUC STUDIES

ISSN 1813-7733

Vol.-12 December 2015

(P. 111-126)

\title{
The Role of Islam in the Yoruba-Hausa Harmonious Relations in Southwestern Nigeria
}

\author{
Muhammad Mukhtar Gatawa, Ph.D. ${ }^{1}$
}

\begin{abstract}
In Nigeria, academic discourse on inter-group relations over the years has been narrowed down to only two interrelated terms: conflict and violence. This is due to the rising cases of inter-ethnic and inter-religious conflicts witnessed in the multi-cultural and multi-religious Nigeria. This paper intends to argue that the escalating ethnic and religious consciousness is greatly the handiwork of elites and politicians who employ both ethnicity and religion as effective tools for mass mobilization and manipulation of citizens' psyche in their attempt to dominate the state power apparatus and resources. It also affirms the view that, as far as the Yoruba and Hausa communities of Agege are concerned, a high level of cordial inter-group relations had been achieved, owing to inter-communal mechanisms developed amongst the Yoruba and Hausa communities over the years of interaction. One of the effective vehicles through which the cordial intercommunal relations are achieved is Islam.
\end{abstract}

\section{Introduction:}

This paper intends to historicise the Yoruba-Hausa intergroup relations that dates back to pre-colonial long distance trade, when Agege was established as a transit camp (Hausa-Zango) by Hausa Kola traders en route to Gonja (Ghana), an important kola producing region. The Community, however, grew up rapidly with the construction of railway line from Lagos to Kano by the beginning of the twentieth century. Thus, the Agege railway station doubled as kolanut market, linking Gonja (Ghana) and Northern Nigeria. The influx of the Hausa into Agege continues to date, due to the position of Lagos as the economic hub of Nigeria. The paper also seeks to assess the role of Islam not only in ensuring mutual commercial relations amongst the Yoruba indigenous community and the stranger Hausa group but equally shapes the existing cordial inter-group relations between the two ethnic groups.

\footnotetext{
1 Department of History, Kaduna State University, Tafawa Balewa Way Kaduna Nigeria, Cell: +234-8027872563, E-mail mmgatawa@gmail.com
} 
Finally, the paper offers an insight on how the 'ethnic/religious identity' provides effective mechanism for the cordial Yoruba-Hausa inter-group relations. The analysis in this paper is adapted from the data collated during the field work conducted from 2006 to 2011 for a doctoral thesis on the Hausa community in Lagos. Besides the few written materials on the subject, extensive interviews and researcher-participation techniques in the data and information gathering were used in the course of the study.

\section{Establishment of Hausa Community in Agege}

The Awori clan of the Yoruba claims to be the founders and pioneer settlers of Agege (Ajayi, 1987). The Awori traditions hold that a certain group of Awori adventurers left Ile-Ife for Isheri and later moved towards the coast and ended up settling at the present day Agege. It is said that the pioneer adventurers of hunter-category were guided in their search by a wise saying that their final destination would be a land divided by river. The narration continues that as they moved on, the thickness of the forest prevented them from advancing further. So the trees (Yoruba - agi) had to be cut off (Yoruba - gege); hence the name Agege (Dawudu, 2007). The initial Awori settlement is said to be at Orile-Agege. As the settlement expanded, the Ogba and Zango-Ota were later incorporated under the control of Agege.

What however might account for the transformation of Agege was the intrusion of large number of Hausa traders and the construction of railway station at the beginning of the twentieth century. Because of the railway line, Agege rapidly rose to prominence in terms of commercial prosperity. The railway station accelerated trading activities at Agege market that consequently made it a commercial hub that brought together people of diverse backgrounds. The extension of railway line to Kano in 1911 further accelerated the influx of Hausa traders into Agege (Hopkins, 1973). The railway line, Lovejoy (1970) observes, did not only attract more Hausa traders to Agege, it also increased the volume of Kola nuts and cattle trade between the Northern and West African Coastal region.

The Hausa community of Agege in Lagos state of Nigeria could be regarded as one of the famous trading/Diaspora communities established during the pre-colonial period in West Africa. The long distance trade by the Hausa people had profound impact on the general economic and 
socio-political landscape of West African region as a whole. The Hausa people had developed entrepreneurial capabilities that contributed to economic development a number of Yoruba towns such as Lagos, Ibadan, Shagamu, Abeokuta, as well as other places in West Africa notably Salaga, Kumasi, Accra, Ouagadougou, to mention a few. Hopkins (1973), Lovejoy (1970) and Adamu (1978) show how Hausa pre-colonial long distance triggered economic prosperity of Agege (Nigeria), Salaga (Ghana) and other towns associated with the kola nut trade. Cohen provides further details on how the trade was conducted on the basis of extensive credit arrangements, between strangers from different locations and tribes, with developed systems of credit, insurance, brokerage, exchange of information, transport and arbitration in commercial disputes. That in spite of substantial amounts of money and large quantity of goods involved, law and order were maintained as all the groups participating in the trade honoured their commercial obligations.

One of the best known ethnic groups associated with the pre-colonial long distance trade in West Africa was the Hausa whose homeland is in the present Northern Nigeria and the neighbouring Niger Republic. The Hausa have been known for high degree of mobility, skill and shrewdness in business. Hence, in the course of the long distance trade, they were able to develop sophisticated economic organization, with network of localized Hausa communities in the major towns of the coastal and forest regions of West Africa.

Moreover, the Hausa communities established in those areas they were trading with in both Yoruland of Nigeria and Gonja in Ghana were formed on the basis of Hausa cultural distinctiveness: Islam, Hausa language, Hausa mode of dress, the institution of Hausa chief (Sarkin Hausawa), a mosque, market and Chief's palace were some of the features associated with Hausa Diaspora communities. By implication, a Hausa long distance trader was not only networking his commercial activities but also acted as Islamic missioner, promoter of Hausa language and culture in all the areas he had commercial networks or where he had settled.

Islam remains a key feature in the distinctiveness of the Hausa trading community in Yorubaland (Adamu, 1978:127-132). Even as Diaspora community, the Hausa maintain their religion. Thus, the transit camp 
(Zango or Sabo) in a Yoruba city is a distinctive social group, with Islam and Hausa culture and language maintained. This apart, Cohen (1971) argues that there was a great relationship between morality and success recorded by the Hausa long distance traders. For Cohen, the success was due to the Islamic moral code of conduct which made trust and credit possible. Such a moral code, he continues, was provided by Islam, the religion of the Hausa. Hopkins (1973:64-65) summarises Cohen's analysis of the role of Islam and its moral code of conduct in the organisation of the long distance trade by asserting that

Successful integration required a formal moral code to sanction and control commercial relationships. The 'blueprint' for the formation of a moral community of businessmen was provided by Islam, which was closely associated with long distance trade in West Africa from the eighth century onwards. Islam helped maintain the identity of members of a network or firm who were scattered over a wide area, and often in 'foreign' countries; it enabled traders to recognise, and hence to deal readily with each other; and it provided moral and ritual sanctions to enforce a code of conduct which made trust and credit possible. It was through Islam that Dioula and Hausa merchants established the commercial networks, or Diasporas, which made them so prominent and successful in long distance trade

Thus, besides serving as unifying factor the Diaspora Hausa community, Islam also attracted other non-Hausa but Muslim Diaspora groups from Northern Nigeria such as Ebira, Kanuri, Shuwa Arabs, Nupe and even those from other West African regions such as Ghanaians and Togolese Kotokoli into major Hausa settlements such as Agege, Sabo Ibadan, Shagamu (Nigeria) and Salaga and Accra (Ghana). Thus, the subsequent Hausa communities established in Lagos and other Yoruba cities from 1970s were composed up of divergent Diaspora communities of various ethnic groups from both northern Nigeria and other West African countries, with Islam and Hausa language as unifying elements.

It is pertinent to note that for the purpose of this discussion, the term 'Hausa' is used as generic term, referring to Hausa and all those people who share some cultural and religious affinity with Hausa, like ability to speak Hausa, dress like Hausa and Muslim by religion, such as Zabarma 
from Niger Republic, Kotokoli from Togo and, Ebira, Kanuri, Shuwa Arabs, Igala from Northern Nigeria and so on.

In the case of Agege Hausa quarters of Lagos, Nigeria, Hausa people according to tradition first settled at Ota among the Aworis. As the Hausa community grew in number, a section of Hausa traders later on moved to Ago-Awusa which was established around the 1930s by one Mallam Abdullahi Usman who migrated from Kano. Ago-Awusa (Hausa camp) was located between Epe and Itokin. The place is now referred to as Alausa in Ikeja, where the Lagos State Government Secretariat is presently located.

The British colonial system increased the migration of Hausa people into Yorubaland. Colonial economic policies such as taxation under a monetized economy, as well as the provision of infrastructure especially the railway encouraged migration and settlements between the north and south of Nigerian (1973). The imposition of the colonial taxes and the insistence of their payment with the new coins were the prime movers in the development of migrant wage labour. Thus, many people became involved in the labour migration to cash crops producing areas and kola nuts trade in search of money to pay taxes. Swindell (1984) reports that

As the twentieth century developed, labour migration clearly took on new dimension and, from what can be inferred, there was a rapid increase in the volume of migration to meet new levels of taxation and demands for labour in the towns and commercial crop zones.

Due to the increase in the population of Hausa traders in Agege in this period (i.e. 1930s), the need to appoint a leader arose. Therefore, in 1934, the first Sarkin Hausawa of Agege, Mallam Haliru, was appointed by Ikeja Native Authority, colony of Lagos (Dawudu, 2007). The death of Sarki Haliru in 1954, and his succession by his son Jubrila, ignited the leadership tussle between the followers of Haliru's camp and those of Muhammadu Dogon Kade. Dogon Kade had served as Magatakarda (secretary) to Sarki Haliru and had contested to succeed Haliru but was overpowered by the formidable Haliru family. Dogon Kade finally became the Sarkin Hausawa of Agege upon the death of Sarki Haliru in 
Attempts at obtaining estimates of the population of the Hausa migrants and settlers in Agege were met with obstacles. Apart from the population Censuses of 1931 and 1951, subsequent census exercises did not either capture data on ethnic backgrounds of respondents or where they did as in 1963 and 1973 the outcome of the exercise was met with public outcry and considered unreliable. Also, a typical Hausa Diaspora group such as found in Yorubaland did pay little or no importance to record keeping apart from that related to goods, credits, trusteeship and associated trade transactions. Moreover, with the rising number of seasonal migrants to Agege, it was difficult to ascertain the number of Hausa community members there. It was thus easier to get estimates of the settlers and those that operated businesses in recognized markets and locations in Agege.

Table 1: Estimates of the Hausa in Lagos and Agege, 1861-2006

\begin{tabular}{|l|l|l|l|}
\hline Year & $\begin{array}{l}\text { Total } \\
\text { Population }\end{array}$ & $\begin{array}{l}\text { Estimate of Hausa } \\
\text { in Lagos }\end{array}$ & $\begin{array}{l}\text { Estimate of Hausa } \\
\text { in Agege }\end{array}$ \\
\hline 1861 & 30,000 & 1,000 & 200 \\
\hline 1871 & 29,000 & 1,500 & 250 \\
\hline 1881 & 37,000 & 3,000 & 500 \\
\hline 1891 & 33,000 & 3,500 & 2,000 \\
\hline 1901 & 42,000 & 4,200 & 2,300 \\
\hline 1911 & 74,000 & 4,700 & 3,000 \\
\hline 1921 & 114,193 & 5,067 & 3,600 \\
\hline 1931 & 126,108 & 7,500 & 4,500 \\
\hline 1951 & 272,000 & 15,000 & 8,000 \\
\hline 1963 & 665,000 & 30,000 & 10,500 \\
\hline 1973 & $2,470,000$ & 250,000 & 40,000 \\
\hline 1991 & $5,685,781$ & $1,000,000$ & 260,000 \\
\hline 2006 & $9,013,634$ & $1,850,000$ & 300,000 \\
\hline
\end{tabular}

Sources: National Archives Ibadan, File No. PX/H1D: Census of Nigeria 1931, Vol. IV: Lagos; File No. PX/H2B: Population Census of Lagos 1950; Federal Office of Statistics, Population Census of Nigeria, 1952 and 1963, Lagos; National Population Commission, Population Census: Lagos State 1991, Government Printer, Lagos, 1992; National Population Commission, Population Census: Lagos State 2006, Government Printer, Lagos, 2007; and interviews and survey conducted at Agege in 2008

Agege was one of the popular camps used and developed by the Hausa long distance traders. Commerce, therefore, was key element in the 
establishment of Agege. The pioneer Hausa community members in Agege and, indeed, subsequent Hausa migrants and settlers in Agege were attracted by the trade opportunities in Agege. Initially, Agege was associated with kola nut trade. Latter, cattle trade became equally prominent due to the demand for meat by the rising population of Lagos. The trio of Agege railway station, market and abattoir became a nucleus of various commercial activities, from which the North-Southwest (Nigeria) and Gonja (Ghana) trade was coordinated by the Hausa..

\section{Yoruba-Hausa Inter-group Relations in Agege}

A number of factors significantly helped shaped the inter-group relation between the Hausa and other ethnic communities in Agege. First, the long established commercial relationship remained a binding force in their relationships. Many Hausa families continued to share the same compounds with the Yoruba where their grandparents used to camp during the pre-colonial kola trade days. The Hausa-Yoruba compounds at Orile-Agege illustrate this kind of mix residential set up. The Hausa and Yoruba residents of the area interviewed considered the social cohesion as one developed over the centuries, recalling the memories of the kola trade period.

The social ties continued to wax stronger with the construction of railway lines linking Lagos and North, and the change of pattern of colonial trade with the emphasis on cash crops such as groundnut and cotton. Both the Yoruba kola and European goods dealers and their Hausa customers mutually shifted their commercial base from OrileAgege to Agege railway station. Market stalls and plots of land at the Agege railway station were equitable shared to both the Yoruba and Hausa. That made the Agege market and railway station to rapidly transform into a significant commercial centre, where kola that was brought from Ghana by steam-engine ships could either be sold up or transported by rail to the Northern Nigeria. The Agege market, adjacent to the rail station, became a depot for cash crops produced in the North.

Second, the relationship developed between the Hausa and Yoruba in Agege over the centuries had brought about inter-ethnic marriages. For instance, a number of Hausa prominent personalities in Agege in particular, and Lagos in general, were maternally Yoruba. A good example is the family of late Sarkin Hausawa of Agege, Jibrilu 
Abdallah. This had led to the emergence of a class of Hausa Yan Kasa who, by virtue of being born and bred in and adapted to the Yoruba community while at the same time retaining their Hausaness, have now became a dominant group in the Hausa-Yoruba affairs in Lagos.

It is, however, interesting to observe some pertinent issues regarding the inter-ethnic marriages between the Hausa and Yoruba in Agege. A survey carried out by the author in Agege in 2007 involving two hundred respondents shows that twenty Hausa men claimed to have had married or were marrying Yoruba women. Surprisingly, none of the two hundred Yoruba male respondents was marrying Hausa woman. The lopsided ratio of the pattern of inter-ethnic marriage between the Hausa and Yoruba in Agege was found to be almost the same in other parts of Lagos where there were concentrations of the Hausa people. Half of the four hundred respondents refused to comment on the factors accounting for high frequency of the Hausa men marrying Yoruba women and the rare frequency of Yoruba men marrying Hausa women.

Those that volunteered to express their opinion on the imbalance in the inter-marriage system offered a wide range of explanations, ranging from socio-cultural to religious. Both Yoruba and Hausa male respondents attributed the phenomenon to the socio-cultural liberty enjoyed by the Diaspora Hausa men in matters of marriage. That culturally a Hausa man could, with little or no resistance from his family members, marry a lady outside of his ethnic group, most especially if they share same religious affinity. It is thus opined that the Yoruba man might enjoy similar freedom; he is culturally bond to marry from within his ethnic group. The trend, however, is static as twenty Yoruba male respondents claimed to have married or knew their kinsmen who were married to non-Yoruba women, but not Hausa. An important finding made from the response of Yoruba groups was that the frequency of Hausa men married to Yoruba women might have been high if not for the rate of divorce in the Hausa community; an act detested in the Yoruba culture. The Hausa Muslim respondents accepted being aware of the rising cases of divorce in their quarters and regarded it as detestable act in Islam.

Another opinion expressed by the Hausa male respondents suggests that a typical Hausa community or family is concerned with the identity 
(cultural and religious) of the person marrying their daughter. The common perception among the Hausa community is that culturally the Hausa woman might on marrying a non-Hausa man lose her cultural identity, besides the common suspicion by an average Hausa Muslim that most non-Hausa Muslims, particularly Yoruba, could make compromises on religious matters. Also, both Hausa male and female respondents expressed their discontentment on the alarming rate at which Yorubas, most especially the youths, convert and revert from one religious faith to another at will. Moreover, the Hausa respondents still hold with suspicion the emphasis placed on culture over religion by the Yoruba. This might have informed the reluctance of the Hausa community members from giving out their daughters to Yoruba for marriage. The suspicion was that a Hausa woman married to a Yoruba man could end up losing her Hausa identity.

On their part, the Yoruba male respondents attributed the rare incidence of their marriage to Hausa women to some cultural differences and the Hausa rigidity in maintaining their Hausa culture. The claim might, to some extent, be true. The history of pre-colonial Hausa migration shows their enduring ability to preserve their culture and Islam as a religion (Adamu, 1978 and Cohen, 1969). These cultural and religious attributes have been maintained by Hausa Diaspora communities. It is this 'rigidness' and uncompromising cultural and religious consciousness by the part of the Hausa that the Yoruba men consider to be a stumbling block in fostering inter-ethnic marriage amongst the two groups.

In Agege, as is case with all other Nigeria's multi-cultural communities, the social-cultural differences had at times led to ethnic conflicts, though minimally. Ebijuwa (2000:84) considers ethnic conflict as ingredient of multi-cultural societies that 'comprise a multitude of religions, ethnic groups with competing interests, competing values and needs'. Conflict is thus inevitable and natural to most societies. Since conflict is inevitable, what the Agege case shows is the historical reconstruction of how societies managed their intergroup conflicts. He further observes that 'societies throughout the world which are stable are not those with an absence of conflict, but rather those which are able to manage conflicts in stable ways'. Other prominent factors that helped shape the historical relationship and contact between the Hausa and Yoruba and assist in the maintenance of stable and harmonious inter-group relations 
between the Hausa community in Agege and its Yoruba hosts are trade, religion, party politics and community associations.

It must, however, be pointed out that the Hausa - non-Hausa relations in Agege, had not been without some frictions. Bamgbose (2009) cited the case of Hausa-Yoruba clash in 1943 when some Yoruba business men and women attempted to partake in the kola trade, to which the Hausa resisted. Nigeria's return to democratic rule in 1999, disappointedly, escalated the scale of inter-ethnic and inter-communal clashes. Theirs was not an isolated case, as Bamgbose reported that between May 1999 and February 2002, Nigeria witnessed some forty ethnic and religious crises. In the case of Agege, Idi-Araba and Mile 12 in Lagos and Shagamu in Ogun state, the clashes always involved Hausa Youth Associations and Yoruba O'dua Peoples' Congress (OPC). Interestingly, the story of the ethnic militias is not all about violence. Some good deeds have been credited to the OPC, especially in the area of combating crime. Later, the various Hausa Associations and OPC began to establish links and take common approach in solving such ethnic misunderstandings.

\section{Yoruba-Hausa Muslim Community in Agege}

The date of the arrival of Islam to Yorubaland remains debatable among scholars. Sheikh Adam Abdullahi El-Ilory (Clarke, 1982:106), the founder of MARKAZ Mosque Agege dates it back to fourteenth century when scholars and traders from Mali began to establish contacts with Yorubaland. Some scholars suggest a sixteenth century date for the arrival of Islam to Yorubaland (Ryan, 1978: Ch.3). Others (such as Law, 977:75) hold the opinion that the history of Islam among the Yoruba probably goes back to the 17th century, when it was introduced, probably from Nupe. Slaves passing into Oyo from the north included Muslims, and a number of itinerant Muslim preachers were travelling in Yorubaland in the late 18th and early 19th centuries. Later, a number of Owu Muslims found their way to Abeokuta and they were joined there by Muslim Saro. In Lagos, urges Gbadamosi (1978), Islam was established in the early 19th century, and there were a number of Muslim traders in the town. It was strengthened during the reign of Kosoko: after his expulsion from Lagos, he founded an important Muslim settlement at Epe in the east. Animashaun is of the opinion that the proportion of 
Muslims in Lagos itself rose from 17 per cent in 1871 to 44 per cent in 1891, and the indigenous Lagosians have been predominantly Muslim ever since.

He further urges that by the beginning of the twentieth century, Muslims in Lagos had become a political force to be reckoned with. In fact Muslims constituted about fifty per cent of the total population of the city. More importantly, as Baker (1974:23) recognises, the Muslims Community had begun to produce a significant number of educated and traditional elite who could articulate political and social issues.

Olukoju (2005:13) is of the opinion that a fairly large Muslim community had been in existence in Agege since the introduction of the religion to the locality by Hausa clerics and traders from Northern Nigeria, well before the late nineteenth century. The construction of a mosque by one Sarki Asani, a migrant from Abeokuta, in 1925 provided a rallying point for Agege Muslims. However, as Olukoju realises, ethnic divisions between Hausa and Yoruba Muslims over succession to the office of Chief Imam caused a sharp division. Hausa Muslims had refused to be led by a Yoruba Chief Imam because the resilience of some indigenous cultural practices among the latter was seen by the Hausa as proof of the syncretism among Yoruba Muslims. The Hausa, therefore, broke away to establish the Sango mosque where they held their own Friday and daily five prayers. From Sango they moved to Masallacin Alhaja (Alhaja Mosque) in the 1960s. Olukoji (Ibid: 12) records that prior to that, the Yoruba had moved from Sarki Asani mosque to Atobaje Central Mosque in 1955.

Division among Muslims in Agege notwithstanding, both the Yoruba and Hausa Muslim communities were initially composed up of Qadiriyya and Tijjaniyya brotherhood followers. Later, the Yoruba established a number of Islamic organisations such as the Anwar-ulIslam (formerly Ahmadiyyah Movement of Nigeria), Ansar-ud-Deen Society and Nasrul Lahil Fathi Society of Nigeria (NASFAT). Similarly, the Hausa Muslim community witnessed the emergence of the Jama'atul Izalatul Bid'a wa Iqamatus Sunnah, (popularly called Izala), which was established in the 1978 in Northern Nigeria and penetrated into the Hausa Diaspora community of Agege by 1980s. It was founded as a movement against negative innovations in Islam and for orthodoxy. 
Kane (2003) analysis of the Movement shows that it was solely established to purify Islam and abolish practices that were not considered original to Qur'an and Sunnah (prophetic tradition). In Agege, as was the case in Northern Nigeria, Izala was fundamentally opposed to the religious practices of the Sufi scholars and customary practices that had through the centuries been incorporated as part of Islam.

It is, however, worth noting that the influential Muslim organizations analysed in this study are categorized by their spread and membership; while some have membership drawn from across both the Yoruba and Hausa Muslims, others were either Yoruba-based or Hausa-based as the case may be. For instance, Anwar-ul-Deen, Ansar-ul-Deen and Nasrul Lahil Fathi Society of Nigeria (NASFAT) remained predominantly Yoruba-based Muslim organization while Izalatul Bidi'a wa IqamatusSunnah (Izala) is largely a Hausa Muslim organization, with few members from Yoruba Muslim elite. On the one hand, the Sufi Muslim orders of Tijjaniya and Qadiriyya have dherents from both the Yoruba and Hausa Muslims but each operated in different camp, maintaining different mosques, dhikr circles and schools.

To the greater Yoruba Muslims, however, Islam has had little effect on the social structure. In inheritance, it is Yoruba customary law rather than Islamic law which is followed, and the same is true in other areas of law. While many descent groups are now almost entirely Christian or Muslim, the rapid spread of the two religions has meant that often pairs of full siblings belong to different religions, and yet they are able to live together amicably.

In public affairs, some care is taken to accommodate both religions. In meetings, if the opening prayers are made by a Muslim, the closing prayers would be made by a Christian. A Christian organizing a funeral or a naming to which Muslims are invited will often have the animals slaughtered by a Muslim.

It is difficult to predict how far religion will create a major cleavage in Yoruba society in the future. In Agege, the groups had become virtually endogamous. As residential units become smaller, it will probably become less common for people of different religions to live together, at least in their home compounds, though rented accommodation will 
remain heterogeneous. On the other hand, schools cut across religious boundaries, and the growth of a literate subculture has tended to obscure religious differences. Given the Yoruba's instrumental attitude to religion and their tolerance of religious pluralism and innovation, it is not surprising as established during the field work in the course of this study from 2006 to 2008 that members of both religions are quite prepared to use the services of other religious specialists when need arises: prominent Alfa or Mallam often have a number of Christian clients.

It should, however, be noted that the cultural differences between the Yoruba and Hausa also characterise the sectarian affiliations of Muslim community in Agege. As was the case in Ibadan in 1950s, separateness of Hausa linguistic-cultural identity found reaffirmation in rallying to the Tijjaniyya tariqa (brotherhood), which provided a religious vessel for the practice of ethnic segmentation (Cohen, 1969). While majority of the Yoruba Muslims are Tijjanis, the Hausa Muslim community is divided into two distinct groups: Tijaniyya and Izala. The Tijaniyya Centre is located at Isale-Agege along Old Abeakuta road, by Agege Market. They, however, run substantial number of Islamiyya schools where the mode of instruction remains the traditional allo system. The Izala Islamiyya schools, on the other hand, have broader curricula. Besides teaching the Qur'an, Hadith and Fiqh, they also introduce pupils to arithmetic, elementary science and English language. Two out of their schools run similar curricula with the State Government's owned schools, with student population of 120 and 154 respectively.

\section{Islam and Conflict Management in Agege}

The Agege Muslim Community plays an important role in conflict management in the Local Government Area. Its intervention has helped to forestall or minimize intra- and inter-group conflicts, which have a potential for snowballing into wider conflagrations. A notable example is the Hausa-Yoruba clashes in Agege in which leaders of religious and ethnic communities have had to interact to take steps to avert reprisal killings in the event of fresh attacks on Yoruba and other Southerners in Northern Nigeria. Unfortunately, it is not always possible to act fast enough to prevent violent clashes. Nevertheless, the Olu of Agege has had to convene peace meetings with leaders of the various groups in 
attendance. Leaders of the Muslim Community across the ethnic divide then ensured that the message of peace was preached in their respective mosques at daily and Jumaat services.

In the field of community development, the Muslim Community has contributed substantially to the educational development of the Local Government Area. Various Islamic Missions have established primary and secondary schools in the area. Indeed, the oldest secondary school in the area and one of the best public secondary schools in Lagos State, Ahmadiyya College, was established in 1943 by the Ahmadiyya Mission in Islam. Moreover, Arabic schools have also been established by such Missions as an aid to religious proselytization. Furthermore, the entire Muslim community has its own journal, Ojise (meaning, the Emissary or Messenger), which not only advances the cause of Islam but facilitates religious tolerance among the people of the area, in particular, and of Yorubaland in general.

The Muslim community is a factor to reckon with in the power equation of Agege Local Government Area. This is because most of the traditional rulers (Oba and Baale inclusive) are Muslims. For example, the Asiwaju of the Muslim Community is also the Ekerin of Agege in his own right. He has deployed this leverage to advance his interests even up to the state level. His support is sought by both politicians and groups in their election campaigns and in advancing their interests.

The Christian community in Agege is equally involved in the power politics of the Local Government Area. It is, however, interesting to note that religion does not feature overtly in the politics of many Yoruba communities. It is remarkable that in 1999 a Christian, Enoch Ajiboso, emerged the popularly elected Chairman of Agege LGA in spite of the preponderant Muslim population in the area. This probably indicates that religion does not count as much as party affiliation, attachment to relevant political patrons and membership of influential social networks. It is not surprising, however, that not a single Hausa man or woman is traced to have had converted to Christianity in Agege, inspite of the long history of Hausa settlement in the area. This possibly reaffirmed Cohen's assertion regarding Ibadan that there was a tendency for a Diaspora Hausa community to maintain its distinctiveness and religion over a long period of time.

\section{Conclusion}

Egwu (2009: 198) has pertinently observed that democratization process has impacted in the rising tide of ethno-communal and religious violence 
in Nigeria. The return to civilian rule in 1999 has raised the level of ethnic and religious consciousness amongst Nigerians. In some cases, as was the case in Jos in 1994 and 2001, the misunderstanding could be due to public or political appointment in which citizens of a given area would be divided on religious lines. In 1953, there was minor misunderstanding between the Yoruba and Hausa over the control of the Kolanut market in Agege. So also in 2001, conflicts broke out between the Yoruba and Hausa communities in Agege, Idi-Araba and Mile 12 Foodstuff Market in Lagos but such incidences did not break the chain of the cordial relations cemented between the two groups over the centuries. One of the vital tools that helps sustain this cordial relationship is, no doubt, Islam, which provides a rallying point for both groups that incidentally are mainly Muslim. The religion also influences the rate of intermarriages amongst the Yourba and Hausa communites.

\section{References}

Abu Abdallah, 62, trader, Markaz Residence Agege, interview, 20 March 2007

Adamu, M., 1978. The Hausa Factor in West African History, Zaria: Ahmadu Bello University Press

Ajayi,. A. et al (Eds.) 1987, History of the Peoples of Lagos State. Lagos: Literamed

Animashaun, M., n.d. The History of Muslim Community of Lagos, Lagos

Anwar- ul Islam Movement of Nigeria, 2005. Brief History of the Anwar- ul Islam Movement of Nigeria, Lgos: n.p.

Baker, P. H., 1974. Urbanisation and Political Change in the Politics of Lagos, 1917 - 1967, Los Angeles: University of California Press

Clark, P. B. 1982. West Africa and Islam: A Study of Religious Developments from the 8th to the 20th Century, London: Edward Arnold

Chief Dawudu (Atobe of Agege), 78, his Capitol Road Palace Agege, Intervie, 17 March 2007

Cohen, A., 1969. Customs and Politics in Urban Africa: A Study of Hausa Migrants in Yoruba Towns, London: Routledge and Kegan Paul

Cohen, A., 1971a. 'Cultural Strategies in the Organization of Trading Diasporas', in Meillassoux, C. (ed.), The Development of Indigenous Trade and Markets in West Africa, Oxford: Oxford University Press

Cohen, A. 1971b. 'The Politics of the Kola Nut Trade', in R. Melson and H. Wolpe (eds.), Nigeria: Modernisation and the Politics of Communalism, East Lansing: Michigan State University Press

Egwu, Sam, 2009. 'Ethnicity, Political Exclusion and Citizenship Rights in Nigeria’, in Ibrahim Muazzam (ed.), The Citizenship Question in Nigeria, Kano: Centre for Research and Development 
Federal Office of Statistics, Population Census of Nigeria, 1952 and 1963, Lagos: Government Printer

Gbadamosi, G. O., 1978. The Growth of Islam among the Yoruba, 1841-1908, London: Longman

Hopkins, A.G. 1973. An Economic History of West Africa, Essex: Longman

Kane, O., 2003. Modernity in Postcolonial Nigeria: A Study of the Movement for the Removal of Innovation and Reinstatement of Traditions, Leiden: Brill

Law, R. C. C. 1977. The Oyo Empire, c. 1600 - 1836, Oxford

Lovejoy, P. E. 1970. The Caravans of Kola, Zaria: Ahmadu

Nasrul Lahil Fathi Society of Nigeria, 2005. Mission \& Vision of NASFAT, Lagos

National Archives Ibadan, File No. PX/H1D: Census of Nigeria 1931, Vol. IV: Lagos

National Archives Ibadan, File No. PX/H2B: Population Census of Lagos 1950

National Population Commission, 1992, Population Census: Lagos State 1991, Lagos: Government Printer

National Population Commission, 2007, Population Census: Lagos State 2006, Lagos: Government Printer

Nnoli, O. 1995. Ethnicity and Development in Nigeria, Aldershot: UNRISD

Ojise : A Monthly Journal of the Agege Muslim Community; theme: 'Peace and Unity'.

Olukoju, A.2005. 'Actors and Institutions in Urban Politics in Nigeria: Agege (Lagos) since the 1950s', Afrika Zamani, 13 \& 14, 155-178, Dakar: CODESRIA

Osaghae, E. E. 1994. Trends in Migrant Political Organisations: The Igbo in Kano, Ibadan: IFRA

Ryan, P. J. 1978. Imale: Yoruba Participation in the Muslim Tradition, Michigan: Ann Arbor

Swindell K. 1984 'Farmers, Traders and Labourers: Dry Season Migration from the North-West Nigeria 1900-1930', AFRICA: Journal of the International Institute, 7 (2): pp. 12-14

Tijani, A.2008. ‘The Hausa Community in Agege, Nigeria 1906-1967’, Journal of Social Sciences, 17 (2), Delhi: Kre Publishers. pp. $173-180$

Ukiwo, U. 2005. 'On the Study of Ethnicity in Nigeria', CRISE Working Paper No. 12, Centre for Research on Inequality, Human Security and Ethnicity (CRISE). Oxford: University of Oxford 